\title{
Myxobolus opsaridiumi sp. nov. (Cnidaria: Myxosporea) infecting different tissues of an ornamental fish, Opsaridium ubangiensis (Pellegrin, 1901), in Cameroon: morphological and molecular characterization
}

Guy Benoit LEKEUFACK-FOLEFACK ${ }^{1}$, Armandine Estelle TCHOUTEZO-TIWA ${ }^{2}$, Jameel AL-TAMIMI ${ }^{3}$, Abraham FOMENA ${ }^{4}$, Suliman Yousef AL-OMAR ${ }^{5} \&$ Lamjed MANSOUR ${ }^{6, *}$

\author{
1,2,4 University of Yaounde 1, Faculty of Science, PO Box 812, Yaounde, Cameroon. \\ ${ }^{3,5,6}$ Department of Zoology, College of Science, King Saud University, PO Box 2455, \\ 11451 Riyadh, Saudi Arabia. \\ ${ }^{6}$ Laboratory of Biodiversity and Parasitology of Aquatic Ecosystems (LR18ES05), \\ Department of Biology, Faculty of Science of Tunis, University of Tunis El Manar, \\ University Campus, 2092 Tunis, Tunisia. \\ ${ }^{*}$ Corresponding author: 1mansour@ksu.edu.sa; lamjed.mansour@gmail.com \\ 1Email: leguyzo@yahoo.fr \\ 2Email: estelle.tiwa@yahoo.com \\ ${ }^{4}$ Email: abfomena@yahoo.fr \\ 5Email: syalomar@ksu.edu.sa
${ }^{1}$ urn:lsid:zoobank.org:author:A9AB57BA-D270-4AE4-887A-B6FB6CCE1676
${ }^{2}$ urn:1sid:zoobank.org:author:27D6C64A-6195-4057-947F-8984C627236D
${ }^{3}$ urn:lsid:zoobank.org:author:0CBB4F23-79F9-4246-9655-806C2B20C47A
${ }^{4}$ urn:1sid:zoobank.org:author:860A2A52-A073-49D8-8F42-312668BD8AC7
${ }^{5}$ urn:1sid:zoobank.org:author:730CFB50-9C42-465B-A213-BE26BCFBE9EB
${ }^{6}$ urn:1sid:zoobank.org:author:2FB65FF2-E43F-40AF-8C6F-A743EEAF3233

\begin{abstract}
We report a new myxozoan, Myxobolus opsaridiumi sp. nov., infecting the ornamental fish Opsaridium ubangiensis (Pellegrin, 1901) collected from the Anga River near the city of Yaounde, Cameroon. Plasmodia were found in the skin, muscles and spleen. The overall prevalence of infection was $54.7 \%$ ( 288 parasitized fish out of 526 examined). The myxospores were ovoid to subspherical in frontal view and lenticular in lateral view. The valves were symmetrical and relatively thick, without edge markings. The myxospore measurements were $10.7 \pm 0.14(10-11.5) \mu \mathrm{m}$ long, $9 \pm 0.15$ (8-10) $\mu \mathrm{m}$ wide and $6.2 \pm 0.7$ (5.6-7.2) $\mu \mathrm{m}$ thick. The two ovoid polar capsules were equal in size, converging and opening together at the anterior end, measuring $5 \pm 0.07(4.3-6.0) \mu \mathrm{m}$ long and $2.7 \pm 0.07$ $(2.2-3.0) \mu \mathrm{m}$ wide. Polar filaments were coiled from 5 to 7 turns. Histopathological analysis revealed no inflammatory reaction associated with the infection. A BLAST search found that the newly obtained 18 rDNA sequence had a low sequence similarity with available sequences for Myxobolus on GenBank. A phylogenetical analysis based on ribosomal DNA partial sequences showed that $M$. opsaridiumi sp. nov. is closely associated with several species of Myxobolus infecting cyprinid fish.
\end{abstract}


Keywords. Myxozoan parasites, fish pathology, new species, Africa, SSU rDNA, phylogeny, histopathology.

Folefack-Lekeufack G.B., Tchoutezo-Tiwa A.E., Al-Tamimi J., Fomena A., Al-Omar S. \& Mansour L. 2021. Myxobolus opsaridiumi sp. nov. (Cnidaria: Myxosporea) infecting different tissues of an ornamental fish, Opsaridium ubangiensis (Pellegrin, 1901), in Cameroon: morphological and molecular characterization. European Journal of Taxonomy 733: 56-71. https://doi.org/10.5852/ejt.2021.733.1221

\section{Introduction}

Myxozoa are cosmopolitan microscopic cnidarians that live as endoparasites of invertebrate and vertebrate hosts, primarily in aquatic environments (Kent et al. 2001; Lom \& Dyková 2006; JiménezGuri et al. 2007). More than 2400 species and 64 genera are recognized (Zhang et al. 2013; Atkinson et al. 2018; Liu et al. 2019; Mathews et al. 2020). They are characterized by morphological simplicity and life-cycle complexity (Fiala et al. 2015). These parasites are identifiable at the spore stage, particularly as actinospores in invertebrate hosts and myxospores in vertebrates. The myxospore is a multicellular structure composed of one to 15 nematocyst-like polar capsules, each containing coiled, extrusible filaments, and at least one ameboid infective germ or sporoplasm (Kent et al. 2001). Infection can be coelozoic, most often in the gallbladder and urinary bladder, or histozoic, targeting skin, muscles, gills or the digestive system. Myxosporean parasites are significant pathogens of fish in both wild and cultured stocks throughout the world, and they are responsible for production losses in farmed fish (Lom \& Dyková 2006). Within the class Myxosporea, the genus Myxobolus includes approximately 900 described species (Eiras et al. 2005, 2014; Kaur \& Singh 2012). Most species infect specific organs, but some have been reported to infect several organs in the same host species (Lekeufack \& Fomena 2013; Eiras et al. 2014).

Until recently, myxosporean species were identified only by the morphological and metric characteristics of the myxospore, organ specificity and tissue tropism (Molnár 1994; Dyková \& Lom 2007). However, classical zoological methods make it difficult to distinguish morphologically similar myxosporean species that can infect identical tissues and develop in closely related host species (Molnár et al. 2002, 2009; Lisnerová et al. 2020). Molecular methods have become increasingly popular tools in parasitological studies to identify myxozoan species (Kent et al. 2001; Mansour et al. 2014; Liu et al. 2016). A combination of morphology and molecular classification, considering host range and tissue specificity, provides a more precise approach to distinguishing valid myxosporeans species from identified taxa (Kent et al. 2001; Fiala 2006; Molnár et al. 2009).

Opsaridium ubangiensis Pellegrin, 1901 is a benthopelagic cypriniform of the family Cyprinidae. It is the single species of its genus present in Lower Guinea, is widely distributed in coastal basins from Cameroon to Congo and can reach more than $120 \mathrm{~mm}$ in length (Stiassny et al. 2007). In addition to its high-quality meat and rapid growth, species of the genus Opsaridium play an important role in national and international pet trades as ornamental (aquarium) fish. Until now, more than 270 species of Myxosporea have been reported to infect African fishes (Deli et al. 2017) and none were known to infect $O$. ubangiensis.

The present study is part of an ongoing investigation to characterize the myxosporean parasites from freshwater fish in Cameroon. Morphological, histological and molecular data were used to describe a new species of Myxobolus that infects the skin, muscles and spleen of O. ubangiensis from the Anga River in Cameroon. 


\section{Material and methods}

\section{Sampling examination}

A total of 526 specimens of Opsaridium ubangiensis were caught with a fine-meshed net from September

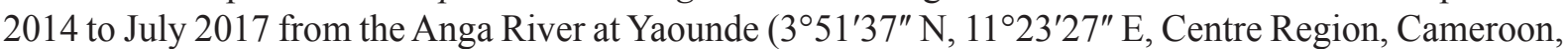
Central Africa). Sampled fish were immediately transported alive to the laboratory of the Department of Parasitology and Ecology at the University of Yaounde 1 in Cameroon, where they were kept in aerated aquaria for identification and parasitological examination. The standard length of the collected fishes ranged from 32 to $117 \mathrm{~mm}$, and identification was carried out according to Stiassny et al. (2007).

In the laboratory, specimens were first examined with the naked eye (eyes, fins, operculum, scales, skin) and then with an Olympus BO61 binocular lens to detect the presence of cysts. After dissection of the hosts, internal organs (gills, heart, liver, kidneys, spleen, gallbladder, gonads and intestines) were removed and examined individually. Some of the recorded cyst contents were identified using an optical microscope with a $100 \times$ objective lens.

\section{Myxospore and histological examinations}

Permanent smears of spores were fixed in methanol and stained with May Grünwald-Giemsa. Drawings of fresh spores were carried out using a wild M20 microscope equipped with a camera lucida. Measurements were made on at least 50 spores as proposed by Lom \& Arthur (1989). Microphotographs of fresh and stained spores were taken using an Olympus BH-2 microscope equipped with a microphotograph.

For histological studies, tissue samples from infected skin, muscle and spleen were fixed in $10 \%$ neutral buffered formalin. The fixed tissue samples were embedded in paraffin wax and then sliced into sections $3 \mu \mathrm{m}$ thick. Sections were stained with hematoxylin and eosin (H\&E) and finally examined and photographed using an Axio Imager Z2 microscope (Carl Zeiss Inc., Berlin, Germany) equipped with a digital camera (Axiocam MRC5, Zeiss). Plasmodia from skin, muscles and spleen were preserved in absolute ethanol for molecular analysis.

\section{Molecular characterization}

Molecular analyses were performed in the Department of Zoology at King Saud University. Genomic DNA was extracted using the DNeasy Blood \& Tissue Kit (Qiagen, Valencia, CA, USA) following the manufacturer's instructions. Partial SSU rDNA gene was amplified using the primers MyxF144 and MyxR1944 (Mansour et al. 2013). Polymerase chain reaction (PCR) amplifications were performed in a $\mathrm{T} 100^{\mathrm{TM}}$ Thermal Cycler (Bio-Rad, Singapore). The PCR program consisted of an initial denaturation step for $5 \mathrm{~min}$ at $94^{\circ} \mathrm{C}$, followed by 35 cycles of $30 \mathrm{~s}$ at $94^{\circ} \mathrm{C}, 30 \mathrm{~s}$ at $56^{\circ} \mathrm{C}$ and $120 \mathrm{~s}$ at $72^{\circ} \mathrm{C}$, and a final extension of $72^{\circ} \mathrm{C}$ for $10 \mathrm{~min}$. All PCR reactions were performed in a final volume of $30 \mu \mathrm{l}$, containing $1 \times$ iProof High Fidelity Master Mix (Bio-Rad, Hercules, CA), $0.2 \mu \mathrm{M}$ of each primer and 50-100 ng of genomic DNA. The PCR products were sequenced by a commercial sequencing company (Macrogen Inc., Seoul, South Korea) using the same primers used for PCR amplification. A consensus sequence was obtained from both sense and anti-sense strands of samples originating from three different PCR products. This consensus sequence was used to query similar sequences of Myxobolus using BLAST in GenBank (Altschul et al. 1997). Sequences were aligned by applying the default parameters in ClustalX ver. 2.1.0.12 (Larkin et al. 2007). Phylogenetic analyses were performed by Bayesian inference (BI) and maximum likelihood (ML) methods. The BI analyses employed MrBayes ver. 3.2 (Ronquist et al. 2012) and the Markov Chain Monte Carlo (MCMC) method for 1500000 generations, with two independent runs of four simultaneous MCMC chains (nchains =4). Trees were saved every 100 generations (sample freq $=100)$. ML analyses were based on the General Time Reversible model with a gamma-distributed rate and invariant sites $(\mathrm{GTR}+\mathrm{G}+\mathrm{I})$ using PhyML ver. 3.0 (Guindon et al. 2010). The analysis involved 22 nucleotide sequences. Positions containing gaps and missing data were removed. 


\title{
Results
}

\author{
Phylum Cnidaria Hatschek, 1888 \\ Unranked Subphylum Myxozoa Grassé, 1970 \\ Class Myxosporea Bütschli, 1881 \\ Order Bivalvulida Schulman, 1959 \\ Suborder Variisporina Lom \& Noble, 1984 \\ Family Myxobolidae Thélohan, 1892 \\ Genus Myxobolus Bütschli, 1882 \\ Myxobolus opsaridiumi sp. nov. \\ urn:lsid:zoobank.org:act:F3105EFD-A1BC-483F-8FC8-5D07FC9B82F0
}

Figs 1-4; Table 1

\section{Etymology}

The specific epithet is related to the host genus name.

\section{Type material}

CAMEROON • infected skin, muscle and spleen of Opsaridium ubangiensis with plasmodia; Centre Region, Anga River, Yaounde; deposited in parasitological collection of the Zoology Department Museum, College of Science, King Saud University, Saudi Arabia; Myxospsar/12/2018.

\section{Taxonomic summary}

\section{Type host}

Opsaridium ubangiense Pellegrin, 1901 (Cyprinidae).

\section{Infected tissues}

Skin, muscles and spleen.

\section{Prevalence}

$54.7 \%$ (288 parasitized fish out of 526 examined).

\section{Vegetative stages}

Ovoid, spherical or ellipsoid plasmodia, variable in size, measuring from $0.3 \mathrm{~mm}$ to $2.5 \mathrm{~mm}$ in length and $0.2 \mathrm{~mm}$ to $1.5 \mathrm{~mm}$ in width.

\section{Description of myxospores (Fig. 1)}

Mature spores were ovoid to subspherical in frontal view and lenticular in lateral view (Fig. 1A-B). The valves were relatively thick, without edge markings. Intercapsular processes were absent. The spore size was $10.7 \pm 0.14(10-11.5) \mu \mathrm{m}$ long, $9 \pm 0.15(8-10) \mu \mathrm{m}$ wide and $6.2 \pm 0.7$ (5.6-7.2) $\mu \mathrm{m}$ thick. The two ovoid polar capsules were equal in size, converging and opening together at the anterior end of the same pore (Fig. 1A, C-D). They measured $5 \pm 0.07$ (4.3-6.0) $\mu \mathrm{m}$ in length and $2.7 \pm 0.07(2.2-3.0) \mu \mathrm{m}$ in width. Polar filaments were coiled from 5 to 7 turns perpendicular to the longitudinal axis of the polar capsules (Fig. 1D). A sporoplasm containing an iodinophilous vacuole of varying shape and size filled the entire space below the polar capsules (Fig. 1A).

\section{Clinical finding and histopathology}

Based solely on gross observation of the fish, no signs of disease were observed. Parasitized fish harbored cysts on skin, muscles and spleen. On skin, white cysts up to $2 \mathrm{~mm}$ long were collected from the body 
flanks of some fish (Fig. 2A). Sections revealed that plasmodia developed in the connective tissue of the dermis beneath the underside of scales (Fig. 2B). Plasmodia were flattened and surrounded by a thin membrane and an internal endoplasm comprising a loosely defined matrix containing developed spores (Fig. 2B).

Some plasmodia were spotted within muscle cells (Fig. 2C). Plasmodia were spindle-shaped, centrally located in the cell and not surrounded by a visible wall. No evidence of inflammation or immune-cell recruitment was seen. The integrity of myofibrils within the infected fibers showed some degree of lysis, with partial loss of myofibrillar details and striations (Fig. 2C-D). These lesions were observed close to plasmodia. Mature spores were scattered in the cytoplasm of infected cells (Fig. 2D).

Infected spleens had plasmodia of up to $2.5 \times 1.5 \mathrm{~mm}$ (Fig. 3A). They were white, isolated or clustered (Fig. 3B). Some infected spleens were heavily infected and plasmodia were randomly distributed in the
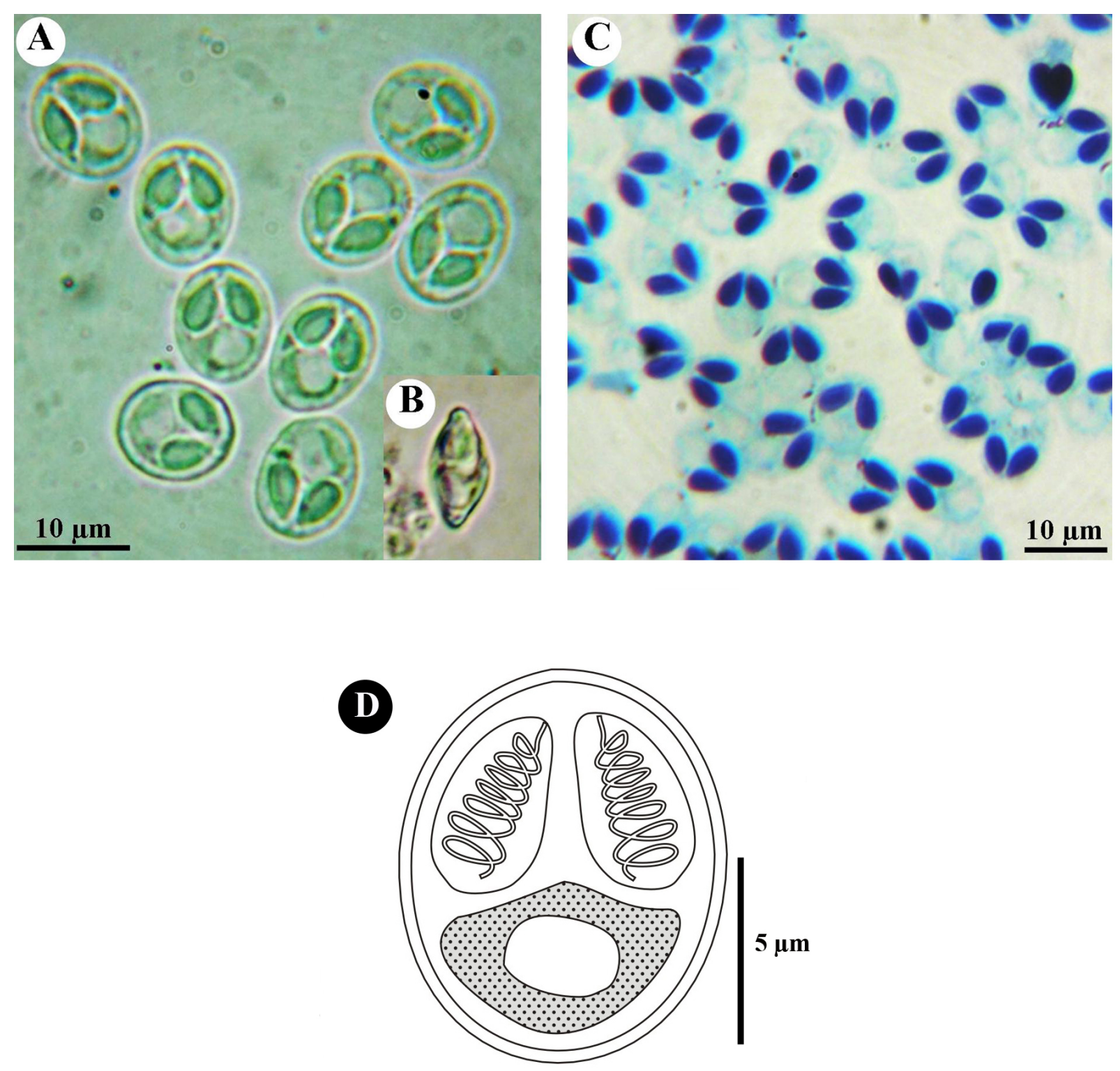

Fig. 1. Photomicrographs of Myxobolus opsaridiumi sp. nov. infecting skin, muscle and spleen of Opsaridium ubangiensis (Pellegrin, 1901). A. Fresh myxospores in frontal view. B. Fresh myxospore in lateral view. C. Giemsa-stained myxospores. D. Diagrammatic drawing of a mature myxospore. 

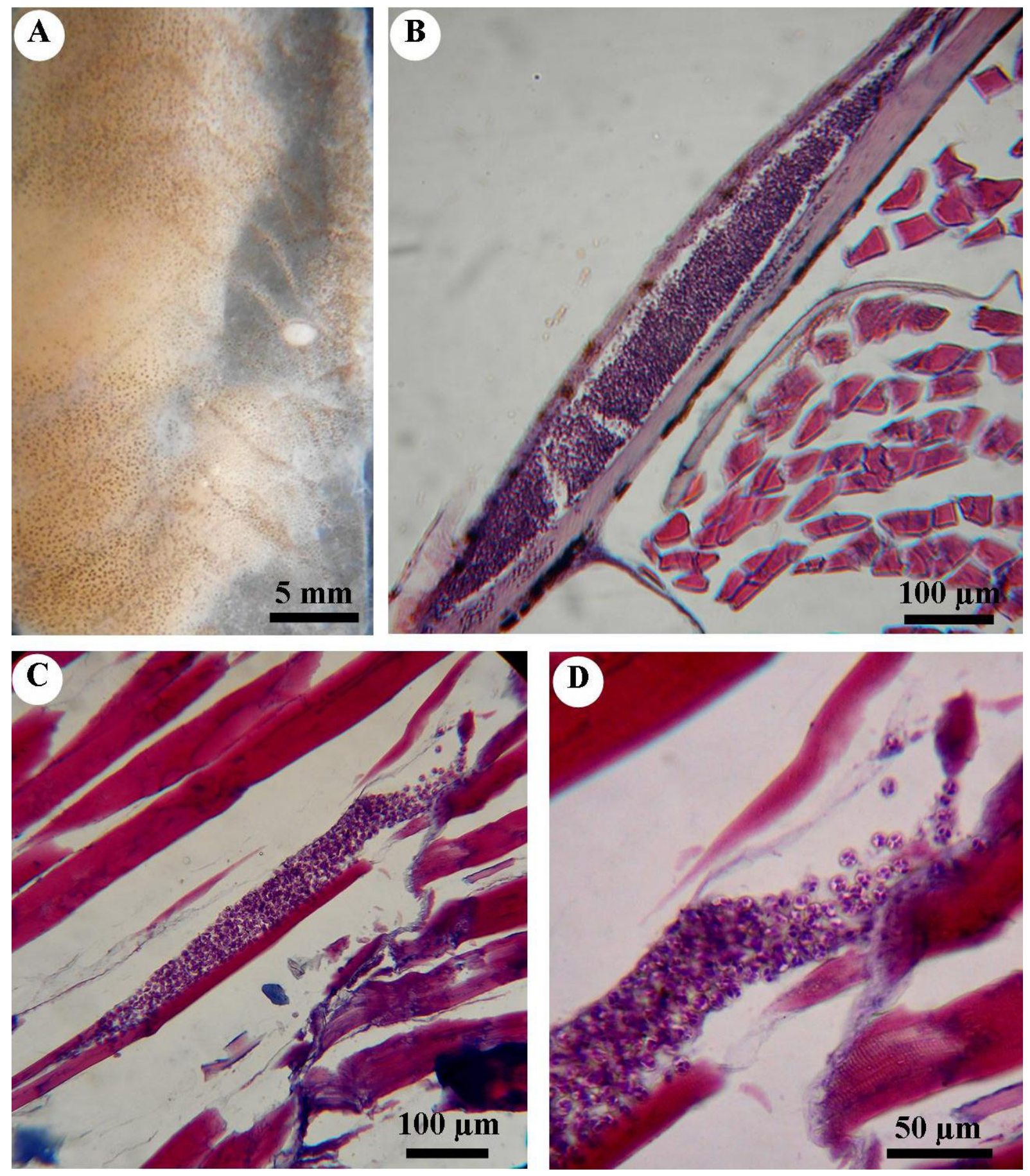

Fig. 2. Photomicrographs of plasmodia of Myxobolus opsaridiumi sp. nov. developing on Opsaridium ubangiensis (Pellegrin, 1901). A. Plasmodium development on the skin. B. Histological section stained with hematoxylin and eosin showing plasmodium situated in the dermis. C. Plasmodium developing within muscle fibers (hematoxylin and eosin). D. Higher magnification of a plasmodium from the muscle fibers. 

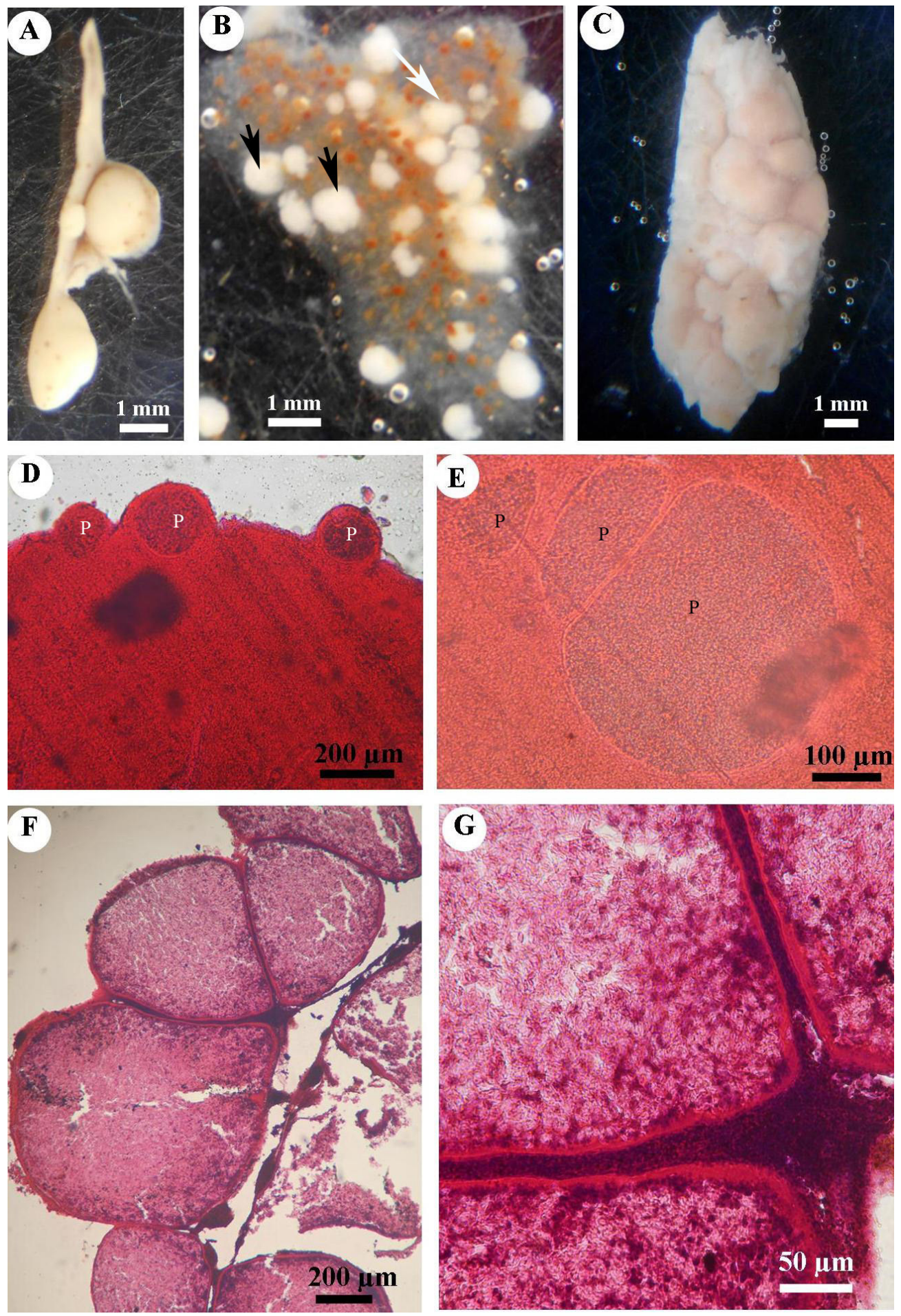

Fig. 3. A-C. Photomicrographs of plasmodia of Myxobolus opsaridiumi sp. nov. affecting a spleen of Opsaridium ubangiensis (Pellegrin, 1901). A. Spleen harbouring large plasmodia. B. Whitish plasmodia isolated from each other (black arrows) or arranged in grape-like clusters (white arrow). C. Spleen completely filled with plasmodia. - D-G. Histological sections stained with hematoxylin and eosin of spleens of $O$. ubangiensis infected with plasmodia of M. opsaridiumi sp. nov. D. Plasmodia implanted on the external region of the spleen. E. Asynchronous development of plasmodia within the spleen. F. Mechanical compression of the cells adjacent to the cysts. G. Higher magnification of plasmodia showing each surrounded by a wall and full of myxospores. Abbreviation: $\mathrm{P}=$ plasmodium. 


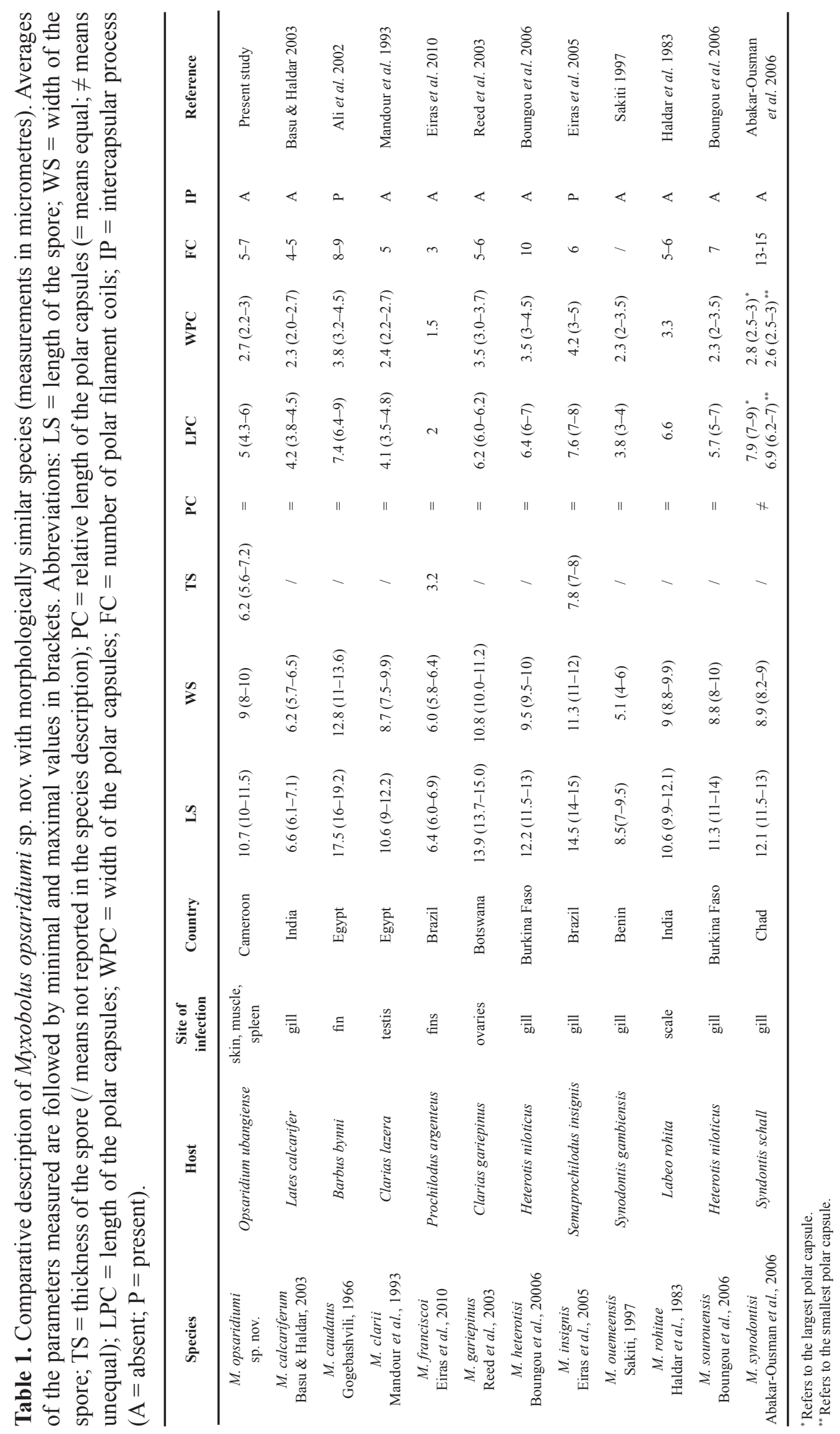


whole organ. In these cases, abnormal enlargement of the spleen was evident (Fig. 3C). Histological sections revealed that, for moderately infected spleens, cysts were either fixed to the external region of the organ (Fig. 3D) or completely implanted within it (Fig. 3E). Development of cysts in the spleen was asynchronous (Fig. 3D-F). Atrophy of the adjacent splenic cells surrounding the cyst was likely due to mechanical compression (Fig. 3F-G). Each plasmodium was surrounded by a wall of a monolayer of flat cells (Fig. 3F-G). The central part of the plasmodium was occupied by fully mature spores, with initial stages of development visible in the periphery (Fig. 3G).

\section{Phylogenetic position}

Partial SSU rDNA sequences obtained from different organs were $100 \%$ identical. The consensus sequence of 1667 base pairs was submitted to GenBank with the accession number MN497413. This sequence did not match any publicly available myxozoan sequence. The sequence with the highest nucleotide similarity, at 91.8\%, was for Myxobolus haichengensis Chen, 1958 (GenBank entry KY965936), which reportedly infects the gills of Abbottina rivularis (Basilewsky, 1855). Similarity with $M$. dibombensis Folefack et al., 2019, a species we recently sequenced from Labeobarbus batesii (Boulenger, 1903) in Cameroon, was only $88.6 \%$.

The phylogenetic position of the newly sequenced species was analyzed with maximum likelihood and Bayesian inference methods. Both methods produced an identical topology. Myxobolus opsaridiumi sp. nov. occurs in a large clade that includes species infecting cyprinids (Fig. 4). The new species exhibits the highest phylogenetic affinity with M. haichengensis, Myxobolus sp. (accession number MG253819) from the fins of Capoeta tinca (Heckel, 1843) off Anatolia, and M. squamae Keysselitz, 1908 infecting the skin of the common barbel Barbus barbus (Linnaeus, 1758).

\section{Discussion}

Based on morphological features of the myxospores infecting the skin, muscle and spleen of Opsaridium ubangiensis, the parasite was assigned to the family Myxobolidae Thelohan, 1892 and the genus Myxobolus Bütschli, 1882. To date, no Myxosporidia had been reported to infect $O$. ubangiensis. This is therefore the first myxobolid infection encountered in this cyprinid fish. Using robust morphological, histological, ecological and molecular data, the described Myxozoa was considered a new species, designated as Myxobolus opsaridiumi sp. nov.

However, some species of Myxobolus infecting other freshwater fishes and showing a similar myxospore morphology, tissue tropism, or geographical location and habitat have been used for comparisons with the new species (Table 1). These species include Myxobolus caudatus Gogebashvili, 1966; M. clarii Mandour, Galal \& Abed, 1993; M. gariepinus Reed, Basson \& Van As, 2003; M. heterotisi Boungou et al., 2006; M. sourouensis Boungou et al., 2006; M. synodontisi Abakar-Ousman et al., 2006; M. ouemeensis Sakiti, 1997; and M. rohitae Haldar, Das \& Sharma, 1983 (Table 1).

In Egypt, Ali et al. (2002) reported M. caudatus in the caudal fin of Barbus bynni (Forsskål, 1775) (Cyprinidae). Myxobolus caudatus differs from our species in that it has a larger myxospore and more developed polar capsules containing more coils of the polar filament (8-9 vs 5-7).

Myxobolus clarii forms cysts in the testis of Clarias gariepinus Burchell, 1822 (synonym: Clarias lazera Valenciennes, 1840) (Clariidae) in Egypt. The myxospores of this species, although ovoid and of comparable size, have a slightly pointed anterior and a rounded posterior. Its polar capsules are relatively small.

Myzobolus gariepinus, a parasite of the ovaries of Clarias gariepinus (Clariidae), which is found in Botswana, forms spores with a small and blunt point at the anterior end and dimensions that exceed the maximum ranges of the spore of the parasite being described, and with more developed polar capsules. 
The polar capsules of M. gariepinus occupy only approximately a third of the spore cavity, while the spore of the species described here has two polar capsules that occupy close to half the space of the spore cavity.

Boungou et al. (2006) described two species of myxosporidia from Burkina Faso with a general shape comparable to that of our parasite, $M$. heterotisi and $M$. sourouensis, which are gill parasites of Heterotis niloticus (Cuvier, 1829) (Osteoglossidae). Myxobolus heterotisi differs from our species in that it has larger spores and more developed polar capsules $(6.41 \times 3.53 \mu \mathrm{m}$ vs $5 \times 2.7 \mu \mathrm{m})$ that contain a polar filament with more coils (10 vs 5-7). Myxobolus sourouensis has longer spores $(11-14 \mu \mathrm{m} \mathrm{vs}$ $10-11.5 \mu \mathrm{m}$ ) which are slightly nippled at the anterior end.

In Chad, Synodontis schall (Bloch \& Schneider, 1801) (Mochokidae) harbors M. synodontisi in its gills. Although of comparable shape, the myxospores of this species are longer. They contain more developed polar capsules, which cover the anterior two-thirds of the myxospore cavity, and are sometimes slightly asymmetrical, with a greater number of coils of the filament (13-15 vs 5-7).

In Benin, Synodontis gambiensis Günther, 1864 (Mochokidae) harbors M. ouemeensis in the cartilaginous tissue of the branchial arch and primary gill filaments. Although comparable in shape, the myxospores of M. ouemeensis are less developed, with shorter polar capsules (3-4 $\mu \mathrm{m}$ vs $4.3-6 \mu \mathrm{m})$.

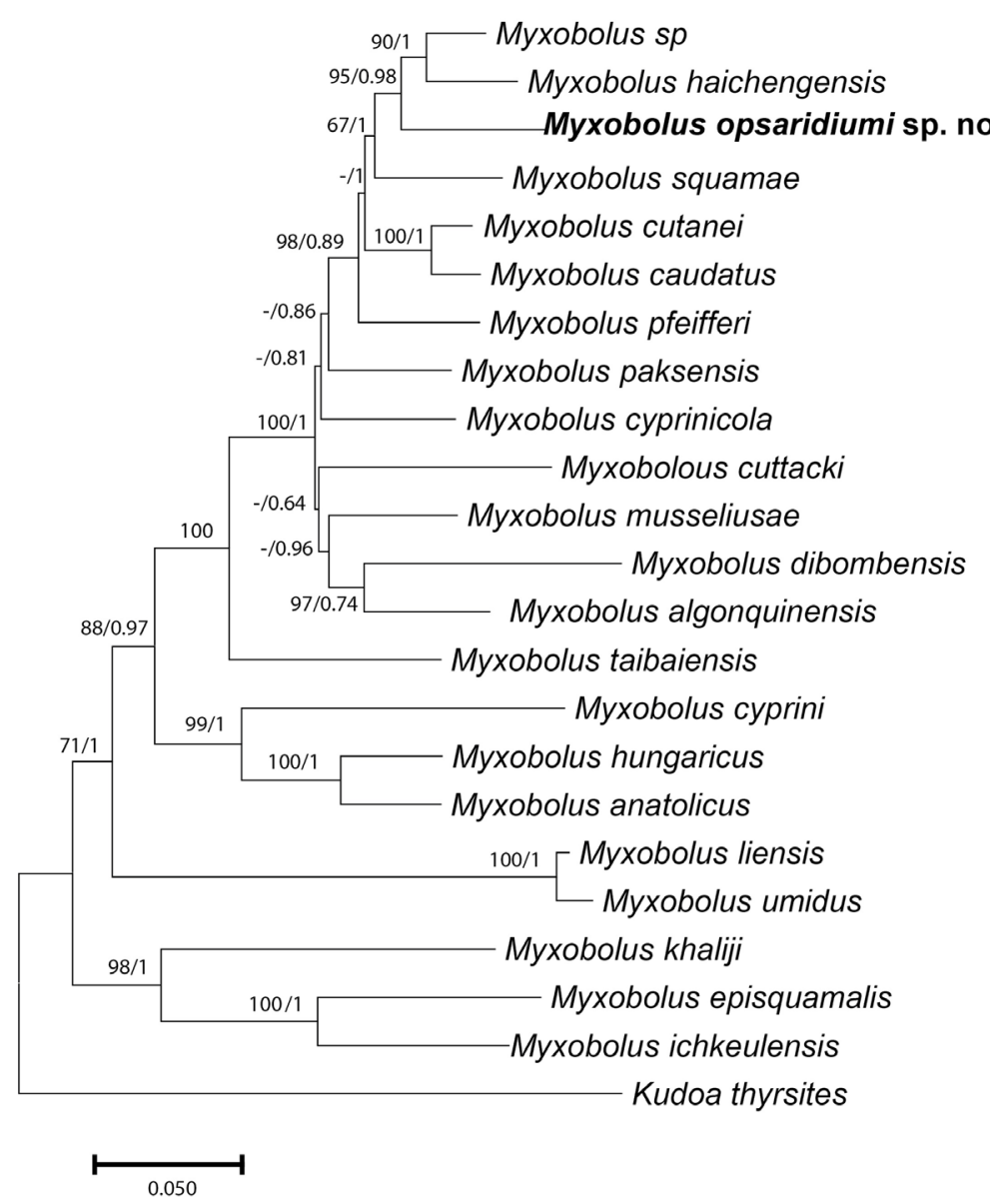

(MG253819) fins

(KY965936) gills

(MN497413) skin, muscle spleen

(JQ3888940) skin

(JQ388890) scales and fins

(JQ388889) scales and fins

(JQ388895) gills and muscles

(KP025687 ) swim bladder

(DQ439805) intestine wall

(KF465682) gills

(FJ710801) gills

(MG737377) fins

(AF378335) ovary

(KU928248) intestine wall

(AF380140) muscle

(AF448444) gills

(KF537629) gills

(MH500003) spleen

(KF296350) spleen

(KC711053) intestinal wall

(AY129312) scales

(AF378337) gills arches

(GU191932)

Fig. 4. Maximum likelihood phylogenetic tree based on the SSU rDNA sequences showing the position of Myxobolus opsaridiumi sp. nov. (in bold) and related species. Accession numbers and infected tissues are listed adjacent to the species names. Numbers at the nodes represent Bayesian posterior probabilities and ML bootstrap percentages. Kudoa thyrsites (Gilchrist, 1924) was used as the outgroup. 
Myxobolus rohitae forms plasmodia on the scales of Labeo rohita Hamilton, 1822 (Cyprinidae) in India. Although of comparable size $(10.6 \times 9$ vs $10.7 \times 9 \mu \mathrm{m})$, the spores of this species have an intercapsular process. In addition, its polar capsules are longer $(6.6 \mathrm{vs} 5 \mu \mathrm{m})$ compared to those of the species being described.

Among all compared species, the $18 \mathrm{~S}$ rDNA sequence of only $M$. caudatus is available in GenBank. This species exhibits $90 \%$ sequence similarity with our present species. The newly obtained sequence diverges substantially from that of all previously sequenced species of Myxobolus. The maximum similarity was obtained with M. haichengensis, which reportedly infects the gill filaments of Abbottina rivularis in China. The single species of Myxobolus sequenced from Cyprinidae collected in Cameroon was $M$. dibombensis (Lekeufack et al. 2019), which exhibited only $83 \%$ similarity. The phylogenetic tree did not show strict clustering of selected species of Myxobolus according to geographic locality or tissue tropism. It is evident that species infecting cyprinids from around the world and different tissues clustered together in the same clade and can be separated from species infecting other hosts from different families and in some cases by tissue tropism. This data is consistent with previous reports, suggesting that phylogenetic affinity of the fish host provided the strongest co-evolutionary congruence (Fiala 2006; Molnar et al. 2011; Zhang et al. 2014; Karlsbakk et al. 2017; Zhao et al. 2020).

In our investigation we found plasmodia of $M$. opsaridiumi sp. nov. in three different organs (skin, muscle and spleen). Studies on the site selection of fish myxosporeans infecting the gills, fins, kidneys and muscle suggest that most myxosporean species have a strict tissue tropism determined by the site of the infected organ used for species identification (Molnár 1994; Molnár \& Székely 2014). Myxozoan parasites are considered as one of the most striking examples of parasite radiation, which could explain their high diversity (Holzer et al. 2018). This great diversity would be acquired by their success in exploiting new hosts and new geographic distributions (Fiala et al. 2015). Adaptation to a new host would be facilitated when the newly exploited species was closely related to the original host within a similar tissue. Another means of radiation is the ability of the same species to explore multiple habitats within the same host and to have the ability to switch in other hosts as well. The selective pressure of the new tissue would be stronger than that of a new related host and is usually associated with evolutionary advantages (Patra et al. 2018). This explains the high specificity of many myxozoan genera and species to the infected tissues, as in the cases of species of Ceratomyxa Thelohan, 1892 infecting the gallbladder and Sphaerospora spp. mostly being parasites of the urinary system.

Myxosporidia infections on the skin are rare but easily observable. The presence of cysts of M. opsaridiumi sp. nov. on the skin did not cause an inflammatory reaction in host fish, with proliferation a direct consequence. According to Lekeufack \& Fomena (2013), the presence and proliferation of cysts of Myxosporidia on the skin are due to the direct contact of this organ with the immediate aquatic environment of the fish, providing an attachment surface to the actinospores.

The histopathological analysis of the skeletal muscle revealed no signs of inflammation or recruitment of phagocyte cells. The integrity of myofibrils within the infected myofibers exhibited some degree of degeneration, with a partial loss of myofibrillar details and striations. These changes were observed in regions close to the plasmodia. Such histopathological observations in the muscle were similar to those reported by Manrique et al. (2015) on Myxobolus sp. infecting the skeletal muscle of Piaractus mesopotamicus (Adriano et al., 2006) in Brazil. Species of the genus Myxobolus were reported in the skeletal muscle of fish (Molnár \& Székely 2014). Pathological effects by species of Myxobolus reported in cyprinid fish include muscle hypertrophy in Leuciscus cephalus (Linnaeus, 1758), Rutilus rutilus (Linnaeus, 1758) and Abramis brama (Linnaeus, 1758) as a result of infection by M. buckei (Longshaw et al., 2003); skeletal muscle infection by spores of M. cyprini Doflein, 1898 in Cyprinus carpio Linnaeus, 1758 and M. pseudodispar Gorbunova, 1936 in R. rutilus reported by Baska (1987). As a result of 
M. artus Akhmerov, 1960 infection in the muscle, Ogawa et al. (1992) observed damaged growth in C. carpio. Most of these pathological changes are responsible for myoliquefaction and the production of meat unfit for consumption (Gilman \& Eiras 1998), with the possibility of food poisoning when the meat is consumed raw or undercooked.

Because teleost fish have no medullary cavity in their bones, the spleen and kidney serve as the primary haemopoietic organs (Agius \& Roberts 2003), and as fish have no lymph nodes, the spleen plays an essential role in antigen trapping (Press 1998). Although some species of Myxobolus reportedly infect the spleen of teleost fish (Eiras et al. 2005, 2014), no histological observations have been made in affected spleens. It appears that M. opsaridiumi sp. nov. can be responsible for damage in the spleen of Opsaridium ubangiensis, as the development of the plasmodia reduces the vessel lumen and in some cases completely obstructs the lumen of the spleen arterioles. A high parasite load could therefore compromise blood circulation and undermine spleen function. Specific patterns of development and the final site of sporogenesis can vary among species of Myxozoa. Without observation of the developing stages it is difficult to determine whether the spores developed at the site of the infection or were carried there by the host's macrophages. This observation led Dyková (1984) to conclude that myxospores are generally transported by macrophages homing in on macrophage centers of hematopoietic organs such as the kidney, spleen and hepatopancreas, where they are destroyed. However, in the present study only vegetative stages of $M$. opsaridiumi sp. nov. were observed in the spleen and no free spores were seen. The spleen is therefore a normal site for M. opsaridiumi sp. nov. sporogenesis.

\section{Acknowledgments}

The authors extend their appreciation to the Deanship of Scientific Research at King Saud University for funding this work through research group RG-1435-023 and to RSSU at King Saud University for their technical support.

\section{References}

Abakar-Ousman A., Fomena P., Ngassam \& Bouix G. 2006. Myxosporidian (Myxozoa) parasites of fresh water fish teleostean from Chad: new or few known species. Annales de l'Université de N'Djamena, Ser. C 1: 111-121.

Agius C. \& Roberts R.J. 2003. Melano-macrophage centres and their role in fish pathology. Journal of Fish Diseases 26: 499-509. https://doi.org/10.1046/j.1365-2761.2003.00485.x

Ali M.A., Al-Rasheid K.A., Sakran T., Abdel-Baki A.-A. \& Abdel-Ghaffar F.A. 2002. Some species of the genus Myxobolus (Myxozoa: Myxosporea) infecting freshwater fish of the River Nile, Egypt, and the impact on their hosts. Parasitology Research 88: 9-15. https://doi.org/10.1007/s004360100449

Altschul S.F., Madden T.L., Schaffer A.A., Zhang J., Zhang Z., Miller W. \& Lipman D.J. 1997. Gapped BLAST and PSI-BLAST: a new generation of protein database search programs. Nucleic Acids Research 25 (17): 3389-3402. https://doi.org/10.1093/nar/25.17.3389

Atkinson S.D., Bartholomew J.L. \& Lotan T. 2018. Myxozoans: Ancient metazoan parasites find a home in phylum Cnidaria. Zoology (Jena) 129: 66-68.

Baska F. 1987. Histological studies on the development of Myxobolus pseudodispar Gorbunova, 1936 in the roach (Rutilus rutilus). Acta Veterinaria Hungarica 35: 251-257.

Basu S. \& Haldar D. 2003. Three new species of Myxobolus Butschli, 1882 from different food fishes of West Bengal, India. Acta Protozoologica 42: 245-251. 
Boungou M., Kabre G.B., Sakiti N.G., Marques A. \& Sawadogo L. 2006. Description of four new myxosporean species (Myxozoa: Myxosporea) from genus Myxobolus, fish parasites of Burkina Faso, West Africa. Journal of Biological Sciences 6 (5): 861-867.

Deli A., Lekeufack F.G.B. \& Abraham F. 2017. Description of Myxidium tetraodoni sp. nov., Myxidium anisocapsularis sp. nov. and Myxobolus magai sp. nov. (Myxosporea: Bivalvulida) infecting some freshwater fishes in Cameroon (Central Africa). Fisheries and Aquaculture Journal 8 (4): 1-11. https://doi.org/10.4172/2150-3508.1000235

Dyková I. 1984. The role of melanomacrophage centres in the tissue reaction to myxosporean infections of fishes. Bulletin of the European Association of Fish Pathologists 4 (4): 65.

Dyková I. \& Lom J. 2007. Histopathology of Protistan and Myxozoan Infections in Fishes. An Atlas. Academia, Prague.

Eiras J.C., Molnár K. \& Lu Y.S. 2005. Synopsis of the species of Myxobolus Bütschli, 1882 (Myxozoa: Myxosporea: Myxobolidae). Systematic Parasitology 61 (1): 1-46.

https://doi.org/10.1007/s11230-004-6343-9

Eiras J.C., Monteiro C.M \& Brasil-Sato M.C. 2010. Myxobolus franciscoi sp. nov. (Myxozoa: Myxosporea: Myxobolidae), a parasite of Prochilodus argenteus (Actinopterygii: Prochilodontidae) from the Upper São Francisco River, Brazil, with a revision of Myxobolus spp. from South America. Zoologia (Curitiba) 27 (1): 131-137.

Eiras J.C., Zhang J. \& Molnár K. 2014. Synopsis of the species of Myxobolus Bütschli, 1882 (Myxozoa: Myxosporea, Myxobolidae) described between 2005 and 2013. Systematic Parasitology 88 (1): 11-36. https://doi.org/10.1007/s11230-014-9484-5

Fiala I. 2006. The phylogeny of Myxosporea (Myxozoa) based on small subunit ribosomal RNA gene analysis. International Journal for Parasitology 36: 1521-1534.

https://doi.org/10.1016/j.ijpara.2006.06.016

Fiala I., Bartošová-Sojková P., Okamura B. \& Hartikainen H. 2015. Adaptive radiation and evolution within the Myxozoa. In: Okamura B., Gruhl A. \& Bartholomew J.L. (eds) Myxozoan Evolution, Ecology and Development: 69-84. Springer International Publishing, Cham, Switzerland.

Gilman M.M. \& Eiras J.C. 1998. Kudoa sp. (Myxosporea, Multivalvulida) infecting Sardina pilchardus (Walb., 1792) off the Portuguese coast. Research and Reviews in Parasitology 58 (2): 135-137.

Guindon S., Dufayard J.F., Lefort V., Anisimova M., Hordijk W. \& Gascuel O. 2010. New algorithms and methods to estimate Maximum-Likelihood phylogenies: assessing the performance of PhyML 3.0. Systematic Biology 59 (3): 307-321. https://doi.org/10.1093/sysbio/syq010

Haldar D.P., Das M.K. \& Sharma B.K. 1983. Studies on protozoan parasites from fishes: four new species of the genera Henneguya Thélohan, 1892, Thelohanellus Kudo, 1933, and Myxobolus Bütschli, 1892. Archiv für Protistenkunde 127 (3): 283-296. https://doi.org/10.1016/S0003-9365(83)80023-2

Holzer A.S., Bartošová-Sojková P., Born-Torrijos A., Lövy A., Hartigan A. \& Fiala I. 2018. The joint evolution of the Myxozoa and their alternate hosts: a cnidarian recipe for success and vast biodiversity. Molecular Ecology 27 (7): 1651-1666. https://doi.org/10.1111/mec.14558

Jiménez-Guri E., Okamura B. \& Holland P.W. 2007. Origin and evolution of a myxozoan worm. Integrative and Comparative Biology 47 (5): 752-758. https://doi.org/10.1093/icb/icm026

Karlsbakk E., Kristmundsson A., Albano M., Brown P. \& Freeman M.A. 2017. Redescription and phylogenetic position of Myxobolus aeglefini and Myxobolus platessae n. comb. (Myxosporea), parasites in 
the cartilage of some North Atlantic marine fishes, with notes on the phylogeny and classification of the Platysporina. Parasitology International 66 (1): 952-959. https://doi.org/10.1016/j.parint.2016.10.014

Kaur H. \& Singh R. 2012. A synopsis of the species of Myxobolus Bütschli, 1882 (Myxozoa: Bivalvulida) parasitising Indian fishes and a revised dichotomous key to myxosporean genera. Systematic Parasitology 81 (1): 17-37. https://doi.org/10.1007/s11230-011-9321-z

Kent M.L., Andree K.B., Bartholomew J.L., El-Matbouli M., Desser S.S., Devlin R.H., Feist S.W., Hedrick R.P., Hoffmann R.W., Khattra J., Hallett S.L., Lester R.J., Longshaw M., Palenzeula O., Siddall M.E. \& Xiao C. 2001. Recent advances in our knowledge of the Myxozoa. Journal of Eukaryotic Microbiology 48 (4): 395-413. https://doi.org/10.1111/j.1550-7408.2001.tb00173.x

Larkin M.A., Blackshields G., Brown N.P., Chenna R., McGettigan P.A., McWilliam H., Valentin F., Wallace I.M., Wilm A., Lopez R., Thompson J.D., Gibson T.J. \& Higgins D.G. 2007. Clustal W and Clustal X version 2.0. Bioinformatics 23 (21): 2947-2948. https://doi.org/10.1093/bioinformatics/btm404

Lekeufack F.G.B. \& Fomena A. 2013. Structure et dynamique des infracommunautés de myxosporidies parasites de Ctenopoma petherici Günther, 1864 (Anabantidae), Clarias pachynema Boulenger, 1903 (Clariidae) et Hepsetus odoe (Bloch, 1794) (Hepsetidae) dans la rivière Sangé au Cameroun. International Journal of Biological and Chemical Sciences 7 (6): 2301-2316. https://doi.org/10.4314/ijbcs.v7i6.11

Lekeufack F.G.B., Abdel-Baki A.S., Ateba N.O.O., Fomena A. \& Mansour L. 2019. Morphological and molecular characterization of Myxobolus dibombensis sp. n. (Myxozoa: Myxobolidae), a parasite of the African carp Labeo barbus batesii (Teleostei: Cyprinidae) from Dibombe River, Cameroon. Parasitology Research 118: 763-771. https://doi.org/10.1007/s00436-019-06209-w

Lisnerová M., Blabolil P., Holzer A., Jurajda P. \& Fiala I. 2020. Myxozoan hidden diversity: the case of Myxobolus pseudodispar Gorbunova, 1936. Folia Parasitologica (Praha) 67: e019.

https://doi.org/10.14411/fp.2020.019

Liu X.H., Batueva M.D., Zhao Y.L., Zhang J.Y., Zhang Q.Q., Li T.T. \& Li A.H. 2016. Morphological and molecular characterisation of Myxobolus pronini n. sp. (Myxozoa: Myxobolidae) from the abdominal cavity and visceral serous membranes of the gibel carp Carassius auratus gibelio (Bloch) in Russia and China. Parasites \& Vectors 9: e562. https://doi.org/10.1186/s13071-016-1836-3

Liu Y., Lövy A., Gu Z. \& Fiala I. 2019. Phylogeny of Myxobolidae (Myxozoa) and the evolution of myxospore appendages in the Myxobolus clade. International Journal for Parasitology 49 (7): 523-530. https://doi.org/10.1016/j.ijpara.2019.02.009

Lom J. \& Arthur J.R. 1989. A guideline for the preparation of species descriptions in Myxosporea. Journal of Fish Diseases 12: 151-156. https://doi.org/10.1111/j.1365-2761.1989.tb00287.x

Lom J. \& Dykova I. 2006. Myxozoan genera: definition and notes on taxonomy, life-cycle terminology and pathogenic species. Folia Parasitologica (Praha) 53: 1-36. https://doi.org/10.14411/fp.2006.001

Longshaw M., Frear P. \& Feist S.W. 2003. Myxobolus buckei sp. n. (Myxozoa), a new pathogenic parasite from the spinal column of three cyprinid fishes from the United Kingdom. Folia Parasitologica (Praha) 50: 251-262. https://doi.org/10.14411/fp.2003.043

Mandour A., Galal A. \& Abed G. 1993. Myxobolus clarii n. sp. in the testis of the fish Clarias lazera from the River Nile of Assiut [Egypt]. Assiut Veterinary Medical Journal 29 (58): 108-114.

Manrique W.G., Figueiredo M.A.P., de Andrade Belo M.A., Martins M.L. \& de Moraes F.R. 2015. First report of Myxobolus sp. infection in the skeletal muscle of Neotropical freshwater fish Piaractus mesopotamicus. Parasitology Research 114: 2041-2044. https://doi.org/10.1007/s00436-015-4454-7

Mansour L., Thabet A., Chourabi K., Harrath A.H., Gtari M., Al Omar S.Y. \& Ben Hassine O.K. 2013. Kudoa azevedoi n. sp. (Myxozoa, Multivalvulida) from the oocytes of the Atlantic horse mackerel 
Trachurus trachurus (Perciformes, Carangidae) in Tunisian coasts. Parasitology Research 112 : 1737 1747. https://doi.org/10.1007/s00436-013-3332-4

Mansour L., Harrath A.H., Abd-Elkader O.H., Alwasel S., Abdel-Baki A.A.S. \& Al Omar S.Y. 2014. Structural and molecular characterization of Kudoa quraishii n. sp. from the trunk muscle of the Indian mackerel Rastrelliger kanagurta (Perciforme, Scombridae) in Saudi Arabia coasts. Parasitology Research 113: 1361-1370. https://doi.org/10.1007/s00436-014-3775-2

Mathews P.D., Mertins O., Milanin T., Espinoza L.L., Flores-Gonzales A.P., Audebert F. \& Morandini A.C. 2020. Molecular phylogeny and taxonomy of a new Myxobolus species from the endangered ornamental fish, Otocinclus cocama endemic to Peru: a host-parasite coextinction approach. Acta Tropica 210: e105545. https://doi.org/10.1016/j.actatropica.2020.105545

Molnár K. 1994. Comments on the host, organ and tissue specificity of fish myxosporeans and on the types of their intrapiscine development. Parasitologia Hungarica 27: 5-20.

Molnár K. \& Székely C. 2014. Tissue preference of some myxobolids (Myxozoa: Myxosporea) from the musculature of European freshwater fishes. Diseases of Aquatic Organisms 107: 191-198.

https://doi.org/10.3354/dao02688

Molnár K., Eszterbauer E., Székely C., Dan A. \& Harrach B. 2002. Morphological and molecular biological studies on intramuscular Myxobolus spp. of cyprinid fish. Journal of Fish Diseases 25: 643652. https://doi.org/10.1046/j.1365-2761.2002.00409.x

Molnár K., Székely C., Hallett S.L. \& Atkinson S.D. 2009. Some remarks on the occurrence, hostspecificity and validity of Myxobolus rotundus Nemeczek, 1911 (Myxozoa: Myxosporea). Systematic Parasitology 72 (1): 71-79. https://doi.org/10.1007/s11230-008-9161-7

Molnar K., Cech G. \& Székely C. 2011. Histological and molecular studies of species of Myxobolus Bütschli, 1882 (Myxozoa: Myxosporea) in the gills of Abramis, Blicca and Vimba spp. (Cyprinidae), with the redescription of M. macrocapsularis Reuss, 1906 and M. bliccae Donec \& Tozyyakova, 1984. Systematic Parasitology 79 (2): 109-121. https://doi.org/10.1007/s11230-011-9292-0

Ogawa K., Delgahapitiya K.P., Furuta T. \& Wakabayayashi H. 1992. Histological studies on the host response to Myxobolus artus Akhmerov, 1960 (Myxozoa: Myxobolidae) infection in the skeletal muscle of carp, Cyprinus carpio L. Journal of Fish Biology 41: 363-371.

https://doi.org/10.1111/j.1095-8649.1992.tb02665.x

Patra S., Sojková P., Peckova H., Fiala I., Eszterbauer E. \& Holzer A. 2018. Biodiversity and hostparasite cophylogeny of Sphaerospora (sensu stricto) (Cnidaria: Myxozoa). Parasites and Vectors 11 (1): e347. https://doi.org/10.1186/s13071-018-2863-z

Press C.M. 1998. Immunology of fishes. In: Pastoret P.P, Griegel P., Bazin H. \& Govaerts A. (eds) Handbook of Vertebrate Immunology: 3-62. Academic Press, San Diego.

Reed C.C., Basson L. \& Van As L.L. 2003. Myxozoans infecting the sharptooth catfish, Clarias gariepinus in the Okavango River and Delta, Botswana, including descriptions of two new species, Henneguya samochimensis sp. n. and Myxobolus gariepinus sp. n. Folia Parasitologica (Praha) 50 (3): 183-189. https://doi.org/10.14411/fp.2003.033

Ronquist F., Teslenko M., van der Mark P., Ayres D.L., Darling A., Hohna S., Larget B., Liu L., Suchard M.A. \& Huelsenbeck J.P. 2012. MrBayes 3.2: efficient Bayesian phylogenetic inference and model choice across a large model space. Systematic Biology 61 (3): 539-542.

https://doi.org/10.1093/sysbio/sys029

Sakiti G.N. 1997. Myxosporidia and Microsporidia Fish Parasites in Southern Benin: Faunal Description, Ultrastructure and Biology. PhD thesis. National University of Benin. 
Stiassny M.L.G., Teugels G.G. \& Hopkins C.D. 2007. Freshwater and brackish fish from Lower Guinea, western Central Africa. In: IRD (ed.) Tropical Fauna and Flora Collection, 1. IRD, Paris.

Zhang J.Y., Gu Z.M., Kalavati C., Costa Eiras J., Liu Y., Guo Q.Y. \& Molnár K. 2013. Synopsis of the species of Thelohanellus Kudo, 1933 (Myxozoa: Myxosporea: Bivalvulida). Systematic Parasitology 86 (3): 235-256. https://doi.org/10.1007/s11230-013-9449-0

Zhang J.Y., Al-Quraishy S. \& Abdel-Baki A.A. 2014. The morphological and molecular characterization of Myxobolus khaliji n. sp. (Myxozoa: Myxosporea) from the double bar seabream Acanthopagrus bifasciatus (Forsskal, 1775) in the Arabian Gulf, Saudi Arabia. Parasitology Research 113 (6): 21772183. https://doi.org/10.1007/s00436-014-3870-4

Zhao Y., Liu X., Xi B., Zhang Q., Li A. \& Zhang J. 2020. Transcriptomic analysis of oligochaete immune responses to myxosporeans infection: Branchiura sowerbyi infected with Myxobolus cultus. Journal of Invertebrate Pathology 169: e107283. https://doi.org/10.1016/j.jip.2019.107283

Manuscript received: 21 September 2020

Manuscript accepted: 10 November 2020

Published on: 2 February 2021

Topic editor: Rudy Jocqué

Desk editor: Danny Eibye-Jacobsen

Printed versions of all papers are also deposited in the libraries of the institutes that are members of the EJT consortium: Muséum national d'histoire naturelle, Paris, France; Meise Botanic Garden, Belgium; Royal Museum for Central Africa, Tervuren, Belgium; Royal Belgian Institute of Natural Sciences, Brussels, Belgium; Natural History Museum of Denmark, Copenhagen, Denmark; Naturalis Biodiversity Center, Leiden, the Netherlands; Museo Nacional de Ciencias Naturales-CSIC, Madrid, Spain; Real Jardín Botánico de Madrid CSIC, Spain; Zoological Research Museum Alexander Koenig, Bonn, Germany; National Museum, Prague, Czech Republic. 